九州大学学術情報リポジトリ

Kyushu University Institutional Repository

Effect of Substrate to Inoculum Ratio on Methane Production and Organic Matter Removal during Solid State Anaerobic Digestion of Beef Manure and Sawdust Mixture

Lee, Seung-Hum

Laboratory of Environmental Economics, Department of Agricultural and Resource Economics, Faculty of Agriculture, Kyushu University | Dept. of Animal Biosystems Science, Chungnam National University

Jo, Hyeon-Soo

Laboratory of Environmental Economics, Department of Agricultural and Resource Economics, Faculty of Agriculture, Kyushu University | Dept. of Animal Biosystems Science, Chungnam National University

Lee, Myung-Gyu

Laboratory of Environmental Economics, Department of Agricultural and Resource Economics, Faculty of Agriculture, Kyushu University | Dept. of Environmental Engineering, Sangji University

Yabe, Mitsuyasu

Laboratory of Environmental Economics, Department of Agricultural and Resource Economics, Faculty of Agriculture, Kyushu University

他

https://doi.org/10.5109/1801783

出版情報：九州大学大学院農学研究院紀要. 62 (1)，pp. 197-203，2017-02-24. Faculty of Agriculture, Kyushu University

バージョン :

権利関係: 


\title{
Effect of Substrate to Inoculum Ratio on Methane Production and Organic Matter Removal during Solid State Anaerobic Digestion of Beef Manure and Sawdust Mixture
}

\author{
Seung-Hun LEE ${ }^{1}$, Hyeon-Soo $\mathrm{JO}^{1}$, Myung-Gyu LEE ${ }^{2}$, Mitsuyasu YABE and Heekwon AHN ${ }^{1 *}$ \\ Laboratory of Environmental Economics, Department of Agricultural and Resource Economics, \\ Faculty of Agriculture, Kyushu University, Fukuoka 812-8581, Japan \\ (Received October 20, 2016 and accepted November 4, 2016)
}

\begin{abstract}
This study was conducted to determine the optimal substrate/inoculum (S/I) ratio for solid state anaerobic digestion (SS-AD) of beef manure and sawdust bedding mixtures. The organic material removal and methane yield performance were evaluated at five different $\mathrm{S} / \mathrm{I}$ levels $(1,2,4,50$, and beef manure alone on a VS basis) for 49 days at $37^{\circ} \mathrm{C}$. Results showed that biodegradable volatile solids (BVS) reduction of beef manure alone test unit was $76 \%$ which was not significantly different from the rest of all inoculated test units. The methane production potential of all five test units showed similar levels (135 to $154 \mathrm{~mL} / \mathrm{g} \mathrm{VS}$ ), regardless of S/I ratio. Although it showed similar methane production potential, the beef manure alone and $\mathrm{S} / \mathrm{I}$ ratio 50 test units showed the highest methane yields of 7.3 and 7.2 based on the volume of methane produced per volume of digester, respectively. In addition, when considering utilization efficiency of the available digester volume, the beef manure alone treatment was 15\% higher than that of the S/I ratio 50 treatment. These results reveal that the beef manure and sawdust bedding mixture does not require inoculation to improve SS-AD performance.
\end{abstract}

Key words: Beef manure, inoculum, solid state anaerobic digestion, biogas, biodegradability

\section{INTRODUCTION}

Approximately 14 million tons of beef manure was produced in South Korea in 2014, which accounted for about 31\% of total livestock manure production (Ahn, 2015). About $90 \%$ of beef farms in South Korea contain bedded pack barns (sawdust bedding), and composting is the most popular method for treating mixtures of manure and bedding material. However, several problems have been observed in the composting process. Because of the increase in bedding material price and stocking rate, the moisture content of collected manure and sawdust mixture is very high, which leads to difficulty in composting. Moreover, about $70 \%$ of farms discharge manure into the field without going through the proper composting process (Ahn, 2015). This practice has led to complaints from surrounding local residents regarding the environment. To increase the utilization of beef manure collected in solid form, advanced alternative technology for conventional composting must be developed.

Anaerobic digestion is advantageous for the treatment of high strength organic wastes such as manure because it produces energy (methane) and solid digestate that can be recycled such as compost or bedding material (Angelodaki and Ahring, 1994; Bonmati et al., 2001). However, only $0.5 \%$ of the total livestock manure produced in South Korea is subjected to anaerobic digestion treatment, and all anaerobic digestion plants are equipped with only liquid anaerobic digesters for treat-

\footnotetext{
Dept. of Animal Biosystems Science, Chungnam National University, Daejeon 305-764, Korea;

2 Dept. of Environmental Engineering, Sangji University, Wonju, Gangwon 220-702, Korea;

* Corresponding author (E-mail:hkahn@cnu.ac.kr)
}

ing swine slurry (Ahn, 2015). Anaerobic digestion processes are classified according to the total solids content. Liquid anaerobic digestion generally occurs at solids content between 0.5 to $15 \%$, whereas solid state anaerobic digestion process occurs feed stocks with solids content higher than 15\% (Li et al., 2011a).

Due to low moisture content of beef manure, it was not considered as a main feedstock material of liquid anaerobic digester. However, solid state anaerobic digestion (SS-AD) system is suitable for treating beef manure because it works well with feed stocks have low moisture content (less than $85 \%$ w.b.).

When compared with liquid phase anaerobic digestion $(\mathrm{L}-\mathrm{AD})$, the $\mathrm{SS}-\mathrm{AD}$ process can treat more organic materials in the same capacity digester while using less energy for heating (Li et al., 2011a). However, the SS$\mathrm{AD}$ requires a long digestion time to decompose organic material because of the high amount of non-biodegradable materials such as cellulose, hemicellulose and lignin. Previous studies have attempted to overcome the disadvantages of solid state anaerobic digestion through physicochemical pretreatment, inoculation, mixing, and moisture content control (Delia and Osman, 2004; Nges and Liu, 2009; Li et al., 2011b).

Overall, inoculation can improve the digestive efficiency, accelerating the methane production rate and reducing digestion time (Raposo et al., 2006). However, depending on the type and characteristics of livestock manure to be treated, selection of an appropriate inoculation ratio is important. If the ratio of the substrate is very low, the utilization efficiency of the available digester volume will be reduced by the excessive amount of inoculum used. Conversely, an excessively high substrate ratio could cause inhibition by accumulation of volatile fatty acids (Alzate et al., 2012). González- 
Fernandez and García-Encina (2009) suggested that anaerobic digestion of swine slurry should be conducted at an S/I ratio of around 1 (COD/VS basis) to prevent from process imbalance results from VFA accumulation. Stabnikova et al. (2008) reported the proper S/I ratio of food waste for anaerobic digestion was 7.7 (VS basis), whereas an S/I ratio of 50 (VS basis) was reported as the optimal S/I ratio for cattle manure (Demirer and Chen, 2008). In previous studies, it should be noted that a lower amount of inoculum was required for cattle manure than for other feedstock materials. This occurs because the digestive organs of ruminants discharge anaerobes with manure that influence the S/I ratio. McGarvey et al. (2007) and Girtija et al. (2013) reported that fresh cattle manure is composed of $30 \%$ to $70 \%$ phyla Firmicutes (strict anaerobic microorganisms). S/I ratio suggested by the Demirer and Chen (2008) cannot be directly applied to the manure collected from unique bedded pack barn prevailed in S. Korea because the characteristics of manure collected from S. Korean style bedded pack barn is different from the cattle manure reported by them.

As time goes on, excreted dairy manure and bedding mixtures are gradually decomposed, the air permeability becomes low, and beef manure that has accumulated on a daily basis to a bedded pack barn will form an anaerobic condition by maintaining moisture content of more than $70 \%$. Moreover, bedding and manure is stepped on by cattle, resulting in an indirect mixing effect that enhances the activity of anaerobic microorganisms in discharged manure. Due to the high activity of anaerobic microorganisms, it may increase the S/I ratio more than the value reported by previous research (ForsterCarneiro et al., 2008).

The purpose of the present study was to look at the optimal substrate to inoculum ratio of beef manure and sawdust bedding mixture as one of the factors likely to induce removal of organic materials, methane production characteristics, and digester stability.

\section{MATERIALS AND METHODS}

\section{Materials}

The beef manure (mixed with sawdust) used in this study was obtained from a beef farm at the Animal Resource Research Center of Chungnam National University and digestate used as the seed material was collected from a sewage treatment plant in Dae-jeon city. Digestate was subjected to starvation under anaerobic conditions at $37^{\circ} \mathrm{C}$ after centrifuging for 30 minutes

Table 1. Characteristics of beef manure and sawdust mixture and inoculum (mean \pm S.D., $n=3$ )

\begin{tabular}{ccc}
\hline Characteristics & Beef manure & Inoculum \\
\hline Moisture Contents (\%, w.b.) & $71.3 \pm 0.3$ & $90.3 \pm 0.7$ \\
Volatile Solids (\%, d.b.) & $83.5 \pm 0.4$ & $64.3 \pm 1.0$ \\
Bulk density (kg m-3) & $692 \pm 6.93$ & - \\
\hline
\end{tabular}

at $3500 \mathrm{rpm}$. The feedstock was stored at $4^{\circ} \mathrm{C}$ prior to use. Characteristics of the beef manure and inoculum used in this study are described in Table 1.

\section{Experimental configuration}

In this study beef manure and inoculum were mixed to achieve different $\mathrm{S} / \mathrm{I}$ ratios of $1,2,4,50$, and 100 (beef manure alone) on a VS basis (Table 2). A lab-scale solid-state anaerobic digestion system with a $2 \mathrm{~L}$ capacity mass cylinder composed of PP (polypropylene) material and digester filled with beef manure and inoculum mixture was sealed using a silicone stopper to maintain anaerobic condition. An internal solid state anaerobic digester was able to separate the liquid and solid phase using PP cylindrical fine-mesh screen (diameter $70 \mathrm{~mm}$, length $200 \mathrm{~mm}$, volume $770 \mathrm{~mL}$, screen opening $1 \mathrm{~mm}$ ). The solid state anaerobic digesters were then maintained for 49 days at $37^{\circ} \mathrm{C}$. The top of the cylinder had a 3-way valve connected to a Tedlar bag to collect the biogas.

Table 2. Experimental conditions

\begin{tabular}{cc}
\hline Items & Substrate ${ }^{\dagger} /$ Inoculum ratio(VS basis) \\
\hline Substrate only & Beef manure $100 \%$ \\
Treatment 1 & $1: 1$, ratio $=1$ \\
Treatment 2 & $2: 1$, ratio $=2$ \\
Treatment 3 & $4: 1$, ratio $=4$ \\
Treatment 4 & $50: 1$, ratio $=50$ \\
\hline
\end{tabular}

note: 'Beef manure and sawdust mixture.

\section{Sampling and analysis}

Approximately $1 \mathrm{~mL}$ liquid samples were taken from the anaerobic digestion reactor using a syringe. Samples were centrifuged at $3500 \mathrm{rpm}$ for $30 \mathrm{~min}$, and then filtered through $1.2 \mu \mathrm{m}$ filter paper. The samples were subsequently analyzed for Soluble Chemical Oxygen Demand (SCOD), Volatile Fatty Acids (VFAs), $\mathrm{NH}_{4}-\mathrm{N}$, and Alkalinity. Moreover, moisture contents and volatile solids were determined from the loss of weight after drying the samples for 24 hours in an oven at $105^{\circ} \mathrm{C}$ and then for $8 \mathrm{~h}$ at $550^{\circ} \mathrm{C}$, respectively.

SCOD analysis was performed using the closed reflux titrimetric method (APHA, 1998) and $\mathrm{NH}_{4}-\mathrm{N}$, alkalinity were analyzed using Gallery ${ }^{\mathrm{TM}}$ automated photometric analyzer (Thermo Fisher Scientific).

VFA was analyzed by injecting the supernatant into an iGC 7200 (DS Science, Korea) with a BP20 column (bore $0.32 \mathrm{~mm}$, length $30 \mathrm{~m}$, film thickness $1.0 \mu \mathrm{m}$ ) and FID (flame ionization detector). Methane contents were analyzed using an iGC 7200 (DS Science, Korea).

\section{Ultimate Biodegradability}

A long time is required to completely decompose the organic material. Total volatile solids (TVS) are composed of biodegradable volatile solids (BVS) and nonbiodegradable volatile solids, but only the BVS are 
decomposed into biogas. Therefore, the decomposition rate of organic materials is more suitable based on the BVS rather than the TVS basis. In this study, the ultimate biodegradability (UB) of a beef manure and sawdust mixture was determined using a graphical statistical method (Tritt and Kang, 1991) to estimate the initial BVS mass. The amount of removed organic materials can be assumed to be the same as the mass of biogas produced due to biodegradable organic materials that were completely decomposed $\left(\mathrm{CH}_{4}\right.$ and $\mathrm{CO}_{2}$; Eq. 1- Eq. 3). In this case, trace gases contained in the biogas were excluded. UB is calculated by a graphical method, linear regression of the remaining volatile solid portion (TVSe) of the initial volatile solid $\left(\mathrm{TVS}_{0}\right)$ at time $t$, as the operating time of the test approached infinity. TVS remaining at infinity was assumed to be the refractory fraction of feedstock $\left(\mathrm{R}_{0}\right)$, which is NBVS.

Next, a linear plot of TVSe/TVS ${ }_{0}$ versus 1 /time to the $\mathrm{y}$-axis was extrapolated to show the refractory fraction as the value of the $y$-intercept. The remaining portion of TVSe/TVS ${ }_{0}$ at any time was calculated by the biogas produced during each interval. The ultimate biodegradability of a substrate is estimated to be UB $=\left(1-\mathrm{R}_{0}\right)$.

$\mathrm{BMR}$ (biomass removed) $=\mathrm{CH}_{4}$ mass $+\mathrm{CO}_{2}$ mass

$$
B M R=\frac{V_{0} \times\left(\frac{16 \mathrm{~g}}{1 \mathrm{~mole}} \times \frac{\mathrm{CH}_{4}}{100}+\frac{44 \mathrm{~g}}{1 \mathrm{~mole}} \times \frac{\mathrm{CO}_{2}}{100}\right)}{\frac{22.413 l}{\text { mole }}}
$$

$\mathrm{BMR}=$ biomass removed $(\mathrm{g})$

$\mathrm{V}_{0}=$ normal state $\left(0^{\circ} \mathrm{C}, 1 \mathrm{~atm}\right)$ biogas volume $(\mathrm{L})$

$\mathrm{CH}_{4}, \mathrm{CO}_{2}=\mathrm{CH}_{4}$ and $\mathrm{CO}_{2}$ contents (\%)

Substituting the $\mathrm{CO}_{2}(\%)=$

$$
100-\mathrm{CH}_{4}(\%) \text { in Eq. (2) yields Eq }
$$

$$
\mathrm{BMR}=V_{0} \times\left\{1.963-\left(0.0124 \times \mathrm{CH}_{4}\right)\right\}
$$

\section{Kinetic modeling (Modified Gompertz)}

Based on the measured methane production, kinetic modeling was conducted using the Gompertz equation to evaluate methanogenesis during SS-AD. Specifically, this was applied to estimate the cumulative methane production by using the characteristics of the methanogenic bacteria growth rate.

$$
M=P \times \exp \left\{-\exp \left[\frac{R_{\mathrm{m}} \times \mathrm{e}}{P}(\lambda-t)+1\right]\right\}
$$

In this equation, $\mathrm{M}$ is the cumulative $\mathrm{CH}_{4}$ production, $\mathrm{mlg}^{-1} \mathrm{vs}$; $\mathrm{P}$ is potential $\mathrm{CH}_{4}$ production, $\mathrm{ml} \mathrm{g}^{-1} \mathrm{vs}$; $\mathrm{Rm}$ is the rate of maximum $\mathrm{CH}_{4}$ production ( $\mathrm{mlg}^{-1} \mathrm{vs}$ day); $\lambda$ is the lag phase period (minimum time to produce biogas) in days; and $\mathrm{t}$ is the cumulative time for $\mathrm{CH}_{4}$ production in days. The parameters $P, \lambda$, and $R_{\mathrm{m}}$ were estimated using the Solver function in MS-Excel.

\section{Statistical analysis}

The Origin Pro software (Origin-Lab, version 8.1) was used for Tukey test. Comparison of experimental accumulative biogas and Gompertz modeling results were done by adjusted regression analysis.

\section{RESULTS AND DISCUSSION}

\section{Variation of $\mathbf{p H}$}

$\mathrm{pH}$ is an important factor that can influence the activity of anaerobes. The ideal $\mathrm{pH}$ for anaerobic digestion is 6.6 to 7.8 , and proper $\mathrm{pH}$ is always necessary to maintain the activity of the digester (Lay et al., 1997). If the activity of methanogenic bacteria is inhibited by changes in the environment, VFA accumulates in the digester, resulting in reduced $\mathrm{pH}$ and failure of the digester. Fig. 1 depicts variations in $\mathrm{pH}$ owing to the difference in $\mathrm{S} / \mathrm{I}$ ratio during $\mathrm{SS}-\mathrm{AD}$. In all treatments, the $\mathrm{pH}$ value decreased during the first 5 days because of VFA accumulation in response to hydrolysis and acidification of organic matter. It was steadily increased after 5 days then maintained around $\mathrm{pH} 7.8$ due to the VFA consumption by methanogens.

Although $\mathrm{pH}$ decreased more with increasing S/I ratio (increasing beef manure content), $\mathrm{pH}$ level maintained proper range $(6.8-7.8)$ throughout the entire experimental period.

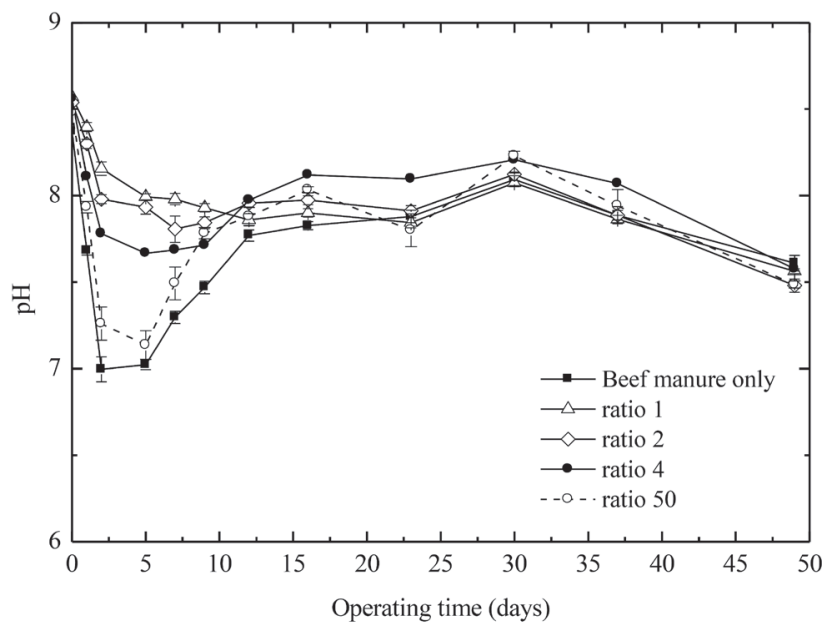

Fig. 1. Variation of $\mathrm{pH}$ in different beef manure to inoculum ratios assayed.

\section{Variation of $\mathrm{NH}_{4}-\mathrm{N}$}

Fig. 2 depicts variations in $\mathrm{NH}_{4}-\mathrm{N}$ concentrations at different $\mathrm{S} / \mathrm{I}$ ratios during $\mathrm{SS}-\mathrm{AD}$. $\mathrm{NH}_{4}-\mathrm{N}$ concentrations of all treatments increased rapidly during the first five days as a result of protein hydrolysis by proteolytic bacteria. In the case of non-inoculated treatment (beef manure alone), the $\mathrm{NH}_{4}-\mathrm{N}$ concentration was about 2.4 times higher than the initial concentration after five days, whereas inoculated treatments (S/I ratio 1, 2, 4 and 50) showed increases of 3.2, 3.7, 4.0 and 4.3 times, respectively. These findings indicate that inoculation can be improved by hydrolysis of protein (Siebert and Toerien, 1969). At the end of the anaerobic digestion period, the $\mathrm{NH}_{4}-\mathrm{N}$ concentrations ranged from 764 to $883 \mathrm{mg} / \mathrm{L}$. Based on these results, the $\mathrm{NH}_{4}-\mathrm{N}$ concentrations of all treatments were lower than $1500 \mathrm{mg} / \mathrm{L}$, which 
has been reported to have toxic effects on the anaerobic digestion process (McCarty, 1964). These findings demonstrated that neither non-inoculated nor inoculated treatments could cause significant $\mathrm{NH}_{4}-\mathrm{N}$ inhibition.

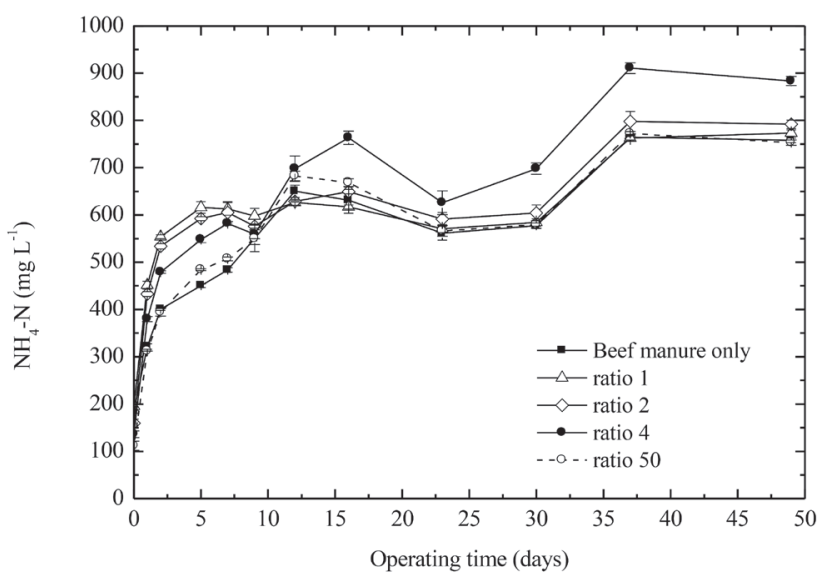

Fig. 2. Variation of $\mathrm{NH}_{4}-\mathrm{N}$ in different beef manure to inoculum ratios assayed.

\section{Variation of VFA}

Volatile fatty acids (VFAs) are one of the important factors for stable anaerobic digestion. In general, VFAs can be used to determine anaerobic digestion process stability as the concentration of VFAs changes in the digester. VFAs are intermediate products of anaerobic digestion that are decomposed by acetogenic and methanogenic bacteria. If the activity of methanogenic bacteria is inhibited, the $\mathrm{pH}$ is decreased by VFA accumulation, eventually leading to failure of anaerobic digestion. Fig. 3 depicts variations in total VFAs (TVFA) concentrations at different $\mathrm{S} / \mathrm{I}$ ratios during $\mathrm{SS}-\mathrm{AD}$. Although the times to reach the maximum TVFA concentration showed the tendency to a steady reduction with decreasing S/I ratio, the maximum TVFA concentration showed trend of significant increment in proportion to $\mathrm{S} / \mathrm{I}$ ratio. The maximum TVFA concentrations obtained were 2087, 267, 544, 1527, and $2760 \mathrm{mg} / \mathrm{L}$ for beef manure alone and treatments with $\mathrm{S} / \mathrm{I}$ ratios of1, 2, 4 and 50 , respectively.

After the maximum VFA concentration was reached, the TVFA concentration decreased and was eventually removed from all treatments due to VFA was consumed by methanogens. The VFA/Alkalinity ratio is also an important indicator of stable anaerobic digestion. In general, when the VFA/Alkalinity ratio is lower than 0.4 , the anaerobic digestion process is stable without accumulation of VFA, while when this ratio is higher than 0.8 , it can lead to failure of anaerobic digestion (Karthikeyan and Visvanathan, 2013). Fig. 4 shows variations in the VFA/Alkalinity ratios at different S/I ratios during SS$\mathrm{AD}$. Continuous increases in VFA/Alkalinity were presented for all treatments during the first 5 days owing to VFA accumulation by accelerating hydrolysis and acidification of organic matter. Regardless of S/I ratio, VFA/ Alkalinity values maintained appropriate range to lead to stable anaerobic digestion throughout the entire experi- mental period.

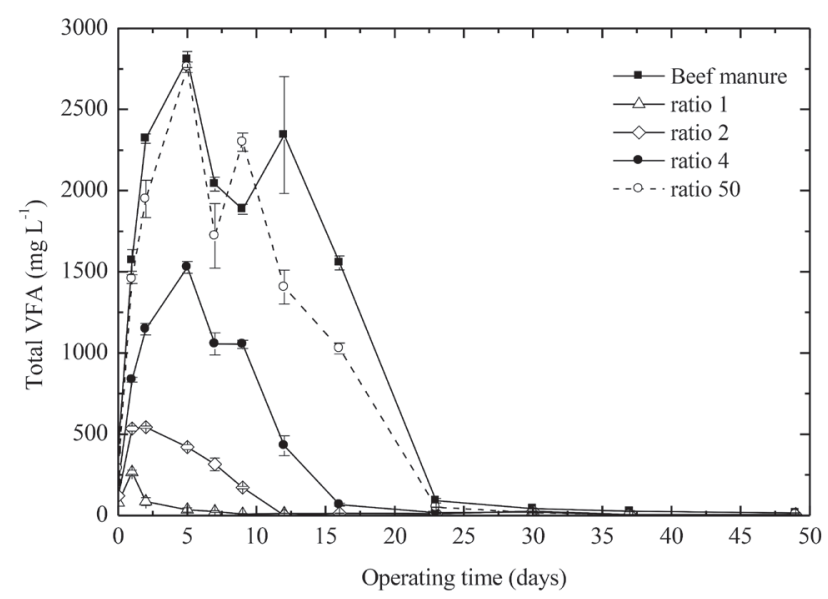

Fig. 3. Variation of TVFA in different beef manure to inoculum ratios assayed.

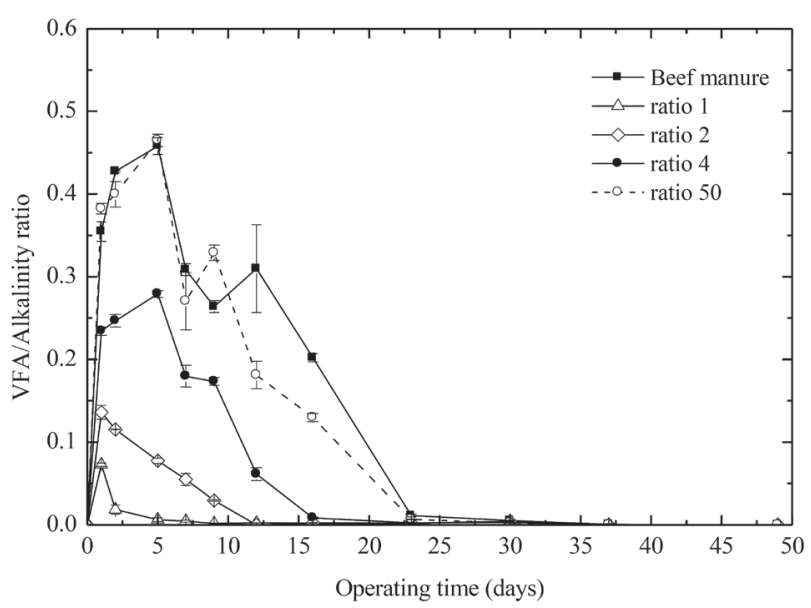

Fig. 4. Variation of VFA/Alkalinity ratio in different beef manure to inoculum ratios assayed.

\section{Organic matter removal}

Table 3 shows the ultimate biodegradability and volatile solids removal achieved under the different S/I ratios during $\mathrm{SS}-\mathrm{AD}$. The ultimate biodegradability of the beef manure and sawdust mixture ranges from 32 to $36 \%$, indicating about $32-36 \%$ of the beef manure and sawdust bedding mixture is composed of biodegradable volatile solids, while about $64-68 \%$ of the remainder is composed of recalcitrant volatile solids. Total volatile solids (TVS) are composed of biodegradable volatile solids (BVS) and non-biodegradable volatile solids (NBVS). Only the BVS can be converted into biogas during anaerobic digestion, therefore BVS removal is more correlated with biogas production then TVS. BVS removal ranges from 68 to $79 \%$. Although beef manure alone and an S/I ratio of 50 showed slightly higher BVS removal performance than others, they were not significantly different $(p>0.05)$.

\section{Methane production rate and kinetic modeling}

Fig. 5 shows the variations in $\mathrm{CH}_{4}$ content at differ- 
Table 3. Summary of ultimate biodegradability and volatile solids removal at different S/I ratios

(Mean土S.E., n=3)

\begin{tabular}{|c|c|c|c|c|c|}
\hline & Initial VS(g) & $\operatorname{BMR}(\mathrm{g})$ & UB (\%) & VS removal (\%) & BVS* removal (\%) \\
\hline Beef manure only & 127.9 & $35.2 \pm 0.2$ & $33.4 \pm 0.2^{\mathrm{a}}$ & $27.5 \pm 0.2^{\mathrm{ab}}$ & $76.2 \pm 0.4^{\mathrm{ab}}$ \\
\hline ratio 1 & 32.8 & $8.0 \pm 0.3$ & $31.6 \pm 0.8^{\mathrm{a}}$ & $24.5 \pm 1.1^{\mathrm{a}}$ & $67.7 \pm 2.4^{\mathrm{a}}$ \\
\hline ratio 2 & 52.1 & $12.8 \pm 0.3$ & $32.0 \pm 0.91^{\mathrm{a}}$ & $24.5 \pm 0.6^{\mathrm{a}}$ & $67.8 \pm 1.4^{\mathrm{a}}$ \\
\hline ratio 4 & 74.1 & $20.1 \pm 0.7$ & $35.8 \pm 1.2^{\mathrm{a}}$ & $27.1 \pm 1.1^{\mathrm{ab}}$ & $75.1 \pm 2.5^{\mathrm{ab}}$ \\
\hline ratio 50 & 110.5 & $31.5 \pm 0.5$ & $36.1 \pm 0.6^{\mathrm{a}}$ & $28.5 \pm 0.6^{\mathrm{b}}$ & $78.9 \pm 1.3^{\mathrm{b}}$ \\
\hline
\end{tabular}

note: 1$)^{\mathrm{a}-\mathrm{b}}$ Means with different superscripts in the same column of each group are significantly different $(\mathrm{p}<0.05)$. 2) $* \mathrm{~S} / \mathrm{I}$ ratio $50 \mathrm{UB}$ basis.

ent $\mathrm{S} / \mathrm{I}$ ratios during $\mathrm{SS}-\mathrm{AD}$. A sharp increase in $\mathrm{CH}_{4}$ concentration was observed in all treatments during the first 7 days, it reached above $60 \%$ regardless of S/I ratios.

Fig. 6 presents the measured and predicted cumulative methane yield with modified Gompertz model. The methane production potential $(\mathrm{P})$ did not differ significantly among groups, with values of 135, 151, 138, 154 and $154 \mathrm{~mL} \mathrm{CH}_{4} / \mathrm{g}$ VS being observed for beef manure alone and with an S/I ratio of 1, 2, 4 and 50, respectively $(\mathrm{p}>0.05)$.

As shown in Table 4, the lag phase $(\lambda)$ of the S/I ratio 1 test units was less than 1day. Although it showed the shortest start-up period, it required significantly

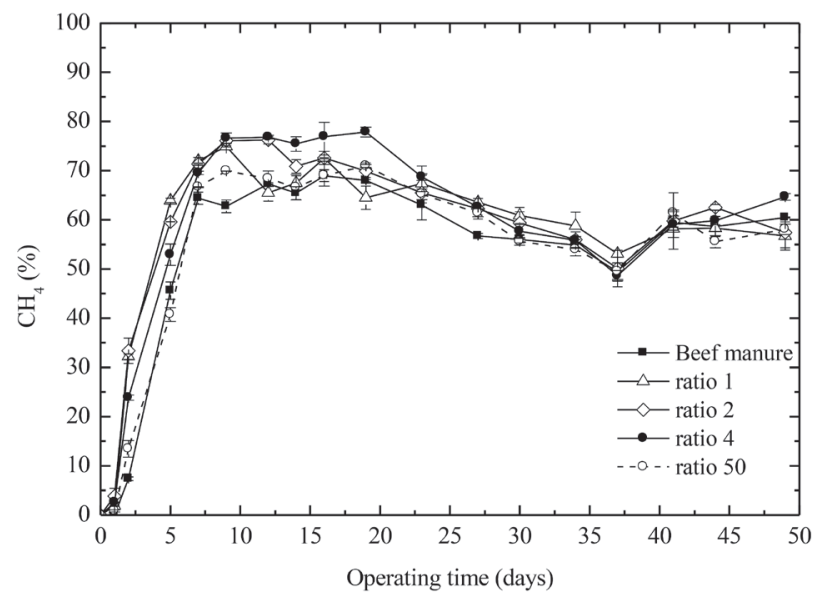

Fig. 5. Variation of methane content in different beef manureto inoculum ratios assayed. longer T95 than other test units $(p<0.05)$. In the case of the S/I ratio 1 test unit, T95 was reached in 52 days, whereas the rest of test units reached maximum methane production at 36 to 40 days. Based on the shortest T95, 36 days, cumulative methane production did not differ significantly among all test units $(p>0.05)$, with values of $126,128,128,147$ and $145 \mathrm{~mL} / \mathrm{gVS}$ being observed for beef manure alone, S/I ratio of 1, 2, 4 and 50, respectively. Although it showed similar cumulative methane production at HRT of 36 days, the beef manure alone and S/I ratio 50 test units showed the highest methane yields of 7.3 and 7.2 based on the volume of methane produced per volume of digester(V/V), respec-

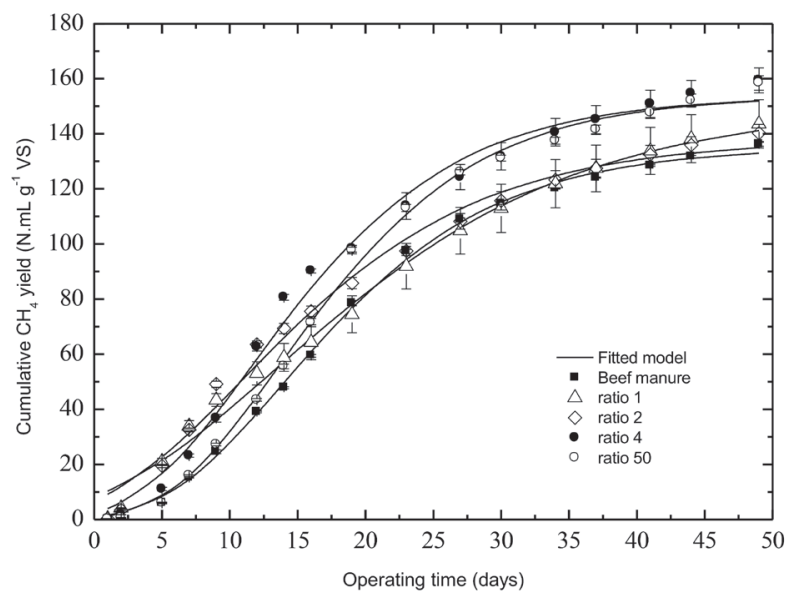

Fig. 6. Measured and predicted cumulative methane yield with modified Gompertz model.

Table 4. Experimental and Gompertz model parameters of cumulative methane production

(Mean \pm S.E., $n=3)$

\begin{tabular}{|c|c|c|c|c|c|}
\hline Parameter & Beef manure only & ratio 1 & ratio 2 & ratio 4 & ratio 50 \\
\hline Cumulative methane yield (mL/gVS) & $136.2 \pm 0.7^{\mathrm{a}}$ & $143.6 \pm 7.1^{\mathrm{ab}}$ & $140.3 \pm 2.6^{\mathrm{ab}}$ & $159.4 \pm 3.7^{\mathrm{b}}$ & $158.4 \pm 2.1^{\mathrm{b}}$ \\
\hline $\mathrm{P}(\mathrm{mL} / \mathrm{gVS})$ & $135.2 \pm 0.9^{\mathrm{a}}$ & $150.5 \pm 5.8^{\mathrm{a}}$ & $137.9 \pm 2.8^{\mathrm{a}}$ & $153.8 \pm 5.0^{\mathrm{a}}$ & $153.9 \pm 1.9^{\mathrm{a}}$ \\
\hline Rm (mL/gVS) & $5.8 \pm 0.1^{\mathrm{a}}$ & $4.4 \pm 0.4^{\mathrm{b}}$ & $5.1 \pm 0.1^{\mathrm{ab}}$ & $6.8 \pm 0.1^{c}$ & $7.0 \pm 0.0^{c}$ \\
\hline $\mathrm{V} / \mathrm{V}^{\dagger}$ in HRT 36 days & $7.3 \pm 0.0^{\mathrm{a}}$ & $1.9 \pm 0.1^{\mathrm{b}}$ & $3.1 \pm 0.1^{\mathrm{c}}$ & $4.9 \pm 0.1^{\mathrm{d}}$ & $7.2 \pm 0.1^{\mathrm{a}}$ \\
\hline
\end{tabular}

Note: 1) ${ }^{a-d}$ Means with different superscripts in the same row of each group are significantly different $(p<0.05)$.

2) Volume of methane produced/Volume of digester. 
Table 5. Utilization efficiency of the available digester volume

\begin{tabular}{cccccc}
\hline & Beef manure (g) & Inoculum (g) & Total amount (g) & $\begin{array}{c}\text { Beef manure } \\
\text { volume (mL) }\end{array}$ & $\begin{array}{c}\text { Rate of digester } \\
\text { utilization (\%) }\end{array}$ \\
\hline Beef manure only & 533.5 & 0.0 & 533.5 & 770.0 & 100.0 \\
ratio 1 & 136.6 & 572.8 & 709.4 & 197.2 & 25.6 \\
ratio 2 & 217.6 & 456.0 & 673.6 & 314.0 & 40.8 \\
ratio 4 & 309.1 & 323.9 & 633.0 & 446.1 & 57.9 \\
ratio 50 & 461.0 & 104.7 & 565.7 & 665.3 & 86.9 \\
\hline
\end{tabular}

tively. However, when considering utilization efficiency of the available digester volume, the beef manure alone treatment was 15\% higher than that of the S/I ratio 50 treatment (Table 5). Therefore, the beef manure alone test unit was determined to be most efficient for treatment of a large amount of beef manure and sawdust mixture within a short period.

\section{CONCLUSION}

The effects of different S/I ratios (beef manure alone, 1, 2, 4 and 50) on methane production and organic matter removal of beef manure and sawdust bedding mixture were evaluated using $\mathrm{SS}-\mathrm{AD}$ system operated in the batch mode under mesophilic conditions $\left(37^{\circ} \mathrm{C}\right)$ for 49 days. All treatments demonstrated adequate stability of anaerobic digestion, regardless of the inoculum ratio, based on parameters indicating $\mathrm{AD}$ process stability including $\mathrm{NH}_{4}-\mathrm{N}$, TVFA and TVFA/ Alkalinity ratio. Although beef manure only test unit showed similar methane production and BVS reduction to the rest of all inoculated test units, it showed the best available digester volume utilization performance. The results reveal that beef manure and sawdust bedding mixture can achieve successful SS-AD performance without inoculation because it contains enough anaerobic microorganisms originated from ruminant to activate anaerobic digestion.

\section{ACKNOWLEDGEMENTS}

This research was funded by the Rural Development Administration (Project No. PJ11694012015) Republic of Korea. However, we received an enormous help from Prof. Myung- Gyu Lee, Sangji University during our study. In particular, a special thanks to Prof. Yabe, Kyushu University in Japan for his collaboration in the experimental design and interpretation of results and help to write research paper in this study.

\section{REFERENCES}

Ahn, H.K. 2015 Current status and future prospective of Korea livestock manure resource recycle technology. Proceeding of $21^{\text {st }}$ conference of the Korean society for livestock housing and environment. Daegu, Korea, pp. 11-26

Alzate, M.E., R. Muñoz, F. Rogalla, F. Fdz-Polanco and S.I. PérezElvira 2012 Biochemical methane potential of microalgae: Influence of substrate to inoculum ratio, biomass concentra- tion and pretreatment. Bioresour. Technol., 123: 488-494 Angelidaki, I. and B.K., Ahring 1994 Anaerobic thermophilic digestion of manure at different ammonia loads: Effect of temperature. Water Res., 28: 727-731

APHA 1998 Standard Methods for the Examination of Water and Wastewaters. American Public Health Association, NW, Washington DC

Bonmati, A., X. Flotats, L. Mateu and E. Campos 2001 Study of thermal hydrolysis as a pretreatment to mesophilic anaerobic digestion of pig slurry. Water Sci. Technol., 44: 109-116

Delia, T. S. and N.A. Osman 2004 Impact of leachate recirculation and recirculation volume on stabilization of municipal solid wastes in simulated anaerobic bioreactors. Process Biochem., 39: $2157-2165$

Demirer, G.N. and S. Chen 2008 Anaerobic biogasification of undiluted dairy manure in leaching bed reactors. Waste Manag., 28: 112-119

Forster-Carneiro, T., M. Perez and L. Romero 2008 Influence of total solid and inoculum contents on performance of anaerobic reactors treating food waste. Bioresour. Technol., 99: 69947002

Girija, D., K. Deepa, F. Xavier, I. Antony and P.R. Shidhi 2013 Analysis of cow dung microbiota - A metagenomic approach. Indian J. Biotechnol., 12: 372-378

Gonzalez-Fernandez, C. and P .A García-Encina 2009 Impact of substrate to inoculum ratio in anaerobic digestion of swine slurry. Biomass and Bioenergy, 33: 1065-1069

Karthikeyan, O. P., and C. Visvanathan 2013 Bio-energy recovery from high-solid organic substrates by dry anaerobic bio-conversion processes: a review. Rev. Environ. Sci. Biotechnol., 12: $257-284$

Lay, J., Y. Li and T. Noike 1997 Influences of $\mathrm{pH}$ and moisture content on the methane production in high-solids sludge digestion. Water Res., 31: 1518-1524

Li, Y., S.Y. Park and J. Zhu 2011a Solid-state anaerobic digestion for methane production from organic waste. Renewable and Sustainable Energy Reviews, 15: 821-826

Li, Y., J. Zhu, C. Wan and S.Y. Park 2011b Solid-state anaerobic digestion of corn stover for biogas production. American Society of Agricultural and Biological Engineers, 54: 14151421

McCarty, P.L. 1964 Anaerobic waste treatment fundamentals, Part 3: Toxic materials and their control, Public Work, Nov., pp. 91-94

McGarvey, J.A., W.G. Miller, R. Zhang, Y. Ma and F. Mitloehner 2007 Bacterial Population Dynamics in Dairy Waste during Aerobic and Anaerobic Treatment and Subsequent Storage. J. Appl. Environ. Microbiol., 73: 193-202

Nges, I. A. and J. Liu 2009 Effects of anaerobic pre-treatment on the degradation of dewatered-sewage sludge. Renew. Energy, 34: 1795-1800

Raposo, F., C.J. Banks, I. Siegert, S. Heaven and R. Borja 2006 Influence of inoculum to substrate ratio on the biochemical methane potential of maize in batch tests. Process Biochem., 41: $444-1450$

Siebert, M. L., and D.F. Toerien 1969 The proteolytic bacteria present in the anaerobic digestion of raw sewage sludge. Water Res., 3: 241-250 
Stabnikova, O., X.Y. Liu and J.Y. Wang 2008 Anaerobic digestion of food waste in a hybrid anaerobic solid-liquid system with leachate recirculation in an acidogenic reactor. Biochem. Eng., 41: 198-201
Tritt, W. P. and H. Kang 1991 Ultimate biodegradability and decay rates of cow paunch manure under anaerobic conditions. Bioresour. Technol., 36: 161-165 